\title{
Peramalan Persediaan Bahan Setengah Jadi Dengan Metode Economical Order Quantity (Eoq) Di Pt. Kayu Lapis Indonesia
}

\section{(Forecasting Work In Process Inventory With The Economical Order Quantity (EOQ) Method In Kayu Lapis Indonesia Ltd.)}

\author{
'B. Erbasakti, S. I. Santoso' ${ }^{2}$ B. M. Setiawan ${ }^{2}$ \\ ${ }^{12}$ Program Studi S1 Agribisnis, Fakultas Peternakan dan Pertanian, \\ Universitas Diponegoro, Tembalang, Semarang 50275 - Indonesia \\ Email: Sakti98@live.com
}

\begin{abstract}
ABSTRAK
Penelitian ini bertujuan untuk menganalisis kuantitas pemesanan ekonomis, persediaan aman, titik pemesanan ulang, dan total biaya persediaan. Lokasi penelitian ditentukan secara purposive di PT Kayu Lapis Indonesia. Metode penelitian yang digunakan adalah Exponential Smoothing dan Economical Order Quantity. Hasil penelitian menunjukkan bahwa peramalan kebutuhan veneer dengan menggunakan metode exponential smoothing didapatkan hasil pada tahun 2020 PT. Kayu Lapis Indonesia membutuhkan veneer sebanyak $24.778,89 \mathrm{~m}^{3}$ dengan kesalahan peramalan (MAD) alpha 0,9 sebesar $8.988,45 \mathrm{~m}^{3}$. Kuantitas pemesanan ekonomis (EOQ) mendapatkan hasil sebesar $1.923,48 \mathrm{~m}^{3}$ dengan frekuensi pemesanan dilakukan 13 kali setahun. Persediaan aman veneer $12.039,76 \mathrm{~m}^{3}$ dan titik pemesanan ulang sebesar $12.272,06 \mathrm{~m}^{3}$. Biaya total persediaan veneer menggunakan metode kuantitas pemesanan ekonomis sebesar Rp 51.529.236,76,-.
\end{abstract}

Kata kunci : Exponential smoothing, Kuantitas pemesanan ekonomis, Peramalan, Persediaan.

\section{ABSTRACT}

This study aims to analyze the economical order quantity, safety stock, reorder points, and total inventory costs. The research location was determined purposively in Kayu Lapis Indonesia Ltd. The research method used is Exponential Smoothing and Economical Order Quantity. The results showed that forecasting veneer needs using the exponential smoothing method obtained in 2020 Kayu Lapis Indonesia Ltd. requires $24,778.89 \mathrm{~m}^{3}$ of veneers with a forecast error (MAD) of alpha 0.9 of $8.988,45 \mathrm{~m}^{3}$. The economic order quantity (EOQ) gets a result of $1,923.48 \mathrm{~m}^{3}$ with the frequency of ordering being done 13 times a year. Safety stock veneer is $12,039.76 \mathrm{~m}^{3}$ and the reorder point is $12,272.06 \mathrm{~m}^{3}$. The total cost of veneer inventory using the economical order quantity method is Rp.51,529,236.76.

Key word: Exponential smoothing, Economical order quantity, Forecasting, Inventory.

\section{PENDAHULUAN}

Hutan di Indonesia mempunyai peranan penting baik di tinjau dari aspek ekonomi, sosial budaya maupun ekologi. kurun waktu tiga dasawarsa terakhir, sumberdaya hutan telah menjadi modal utama pembangunan ekonomi nasional, dengan memberikan dampak yang positif bagi peningkatan penerimaan pemerintah, penyerapan tenaga kerja dan mendorong pengembangan wilayah dan pertumbuhan ekonomi (Ulya dan Yunardy, 2006).
Perusahaan di Indonesia yang bergerak di sektor industri perkayuan dan memberikan kontribusi dalam pembangunan nasional contohnya adalah PT. Kayu Lapis Indonesia. Perusahaan PT. Kayu Lapis Indonesia merupakan perusahaan yang memproduksi berbagai jenis kayu lapis (plywood) seperti triplek dan blackboard. Produk kayu lapis ini menggunakan bahan baku utama berupa kayu gelondong yang masih utuh (log) yang kemudian diolah menjadi bahan 
setengah jadi yang disebut veneer. Perusahan perlu sebuah strategi manajemen yang tepat untuk memperoleh keuntungan yang optimal, salah satunya manajemen penyediaan bahan setengah jadi. Suatu usaha perlu sebuah manajemen yang tepat untuk mengalokasikan sumber dayanya supaya tidak terjadi kekurangan atau kelebihan bahan setengah jadi. Manajemen persediaan stok barang merupakan merupakan masalah penting yang dihadapi oleh perusahaan khususnya perusahaan dagang, maka dari itu persediaan harus dikelola dengan sebaikbaiknya (Wildana dan Utami, 2017).

Kesalahan yang sering terjadi pada perusahaan yaitu pembelian veneer kurang diperhitungkan secara detail dan kurang memperhatikan prediksi permintaan di masa yang akan datang. Perlu adanya strategi yang tepat untuk menghindari terjadinya kekurangan atau kelebihan bahan pembuatan kayu lapis yang menyebabkan proses produksi tidak efektif dan efisien serta supaya perusahaan mampu menyediakan produk yang dibutuhkan oleh pasar hingga di tahun-tahun berikutnya. Metode yang dapat digunakan untuk merumuskan strategi penyediaan bahan setengah jadi untuk produksi kayu lapis salah satunya adalah metode Economical Order Quantity (EOQ). Tujuan dari penelitian ini adalah menganalisis kuantitas pemesanan ekonomis, persediaan aman, titik pemesanan ulang, biaya total persediaan bahan setengah jadi

\section{METODE PENELITIAN}

Penelitian dilaksanakan pada bulan November-Desember 2019 PT. Kayu Lapis Indonesia, Desa Mororejo, Kecamatan Kaliwungu, Kabupaten Kendal, Jawa Tengah. Penentuan lokasi dilakukan secara purposive dengan pertimbangan bahwa PT. Kayu Lapis
Indonesia mengekspor hasil produksi ke berbagai negara seperti Amerika, Jepang, dan Eropa. Menurut Greenpeace, Pabrik Kayu Lapis Indonesia terbesar di Indonesia yang berada di satu lokasi. Memiliki Sistem Verifikasi Legalitas Kayu (SVLK).

Data yang digunakan dalam penelitian ini adalah data primer dan data sekunder. Data primer diperoleh dari observasi proses produksi bahan setengah jadi hingga bahan jadi dan wawancara langsung dengan manajer bagian pengadaan bahan setengah jadi. Data sekunder diperoleh dari dokumen perusahaan, jurnal, internet dan literatur yang menunjang dalam penelitian ini. Sumber data yang dibutuhkan untuk pengendalian persediaan bahan setengah jadi meliputi data total kebutuhan per periode, biaya pesanan per pemesanan meliputi biaya transportasi dan pembongkaran, dan biaya administrasi, biaya penyimpanan per unit/ periode meliputi biaya pemeliharaan dan biaya kerusakan, harga beli per unit, waktu tunggu. Data pada variabel independen dilakukan dengan pengamatan berkelanjutan atau time series selama 3 tahun (Komalasari, 2008). Data time series yang digunakan merupakan data trend tahunan selama 10 tahun.

Alat analisis data yang digunakan untuk menganalisis data penelitian ini meliputi moving average, exponential smoothing, least square, mean absolute deviation, kuantitas pemesanan ekonomis, persediaan aman, titik pemesanan ulang, dan total biaya persediaan.

Metode moving average yaitu metode peramalan yang menggunakan rata-rata dari sejumlah $(n)$ data terkini untuk meramalkan periode mendatang. Nilai peramalan dihitung menggunakan rumus sebagai berikut : 


$$
Y_{t+1}=\frac{Y_{t}+Y_{t}+\ldots+Y_{t-n+1}}{m}
$$

Keterangan :

$Y_{t+1}$ : Nilai ramalan pada periode $(t+1)$

$Y_{t} \quad$ : Nilai sebenarnya/ aktual pada periode $t$

m : Banyaknya waktu dalam moving average

Exponential Smoothing adalah salah satu tipe teknik peramalan rata-rata bergerak dengan melakukan penimbangan terhadap data masa lalu dengan cara eksponensial sehingga data paling akhir mempunyai bobot atau timbangan lebih besar dalam rata-rata bergerak. Nilai peramalan dihitung menggunakan rumus sebagai berikut:

$$
\mathrm{F}_{t+1}=\alpha X_{t}+(1-\alpha) F_{t}
$$

Keterangan :

$$
\begin{array}{ll}
\mathrm{X}_{t} & : \text { Data permintaan pada periode } \mathrm{t} \\
\alpha & : \text { Faktor/konstanta pemulusan }(0<\alpha<1) \\
\mathrm{F}_{t+1} & : \text { Peramalan untuk periode } \mathrm{t}+1
\end{array}
$$

Metode Kuadrat Terkecil (Least Square Method) adalah metode untuk menghitung nilai trend pada tahun berjalan dan untuk mencari forecast pada periode yang akan datang. Nilai peramalan dihitung menggunakan rumus sebagai berikut :

$\mathrm{Y}=\mathrm{a}+\mathrm{bX}$

$\mathrm{a}=\frac{\sum \mathrm{Y}}{n}$ dan $\mathrm{b}=\frac{\sum \mathrm{X}^{2}}{\sum \mathrm{XY}}$

Keterangan :

$\begin{array}{ll}\mathrm{Y} & \begin{array}{l}\text { : Data time series yang akan } \\ \text { diperkirakan }\end{array} \\ \mathrm{X} & : \text { variabel waktu } \\ \mathrm{a} \text { dan b } & \text { : konstanta dan koefisien }\end{array}$

Metode untuk mengevaluasi metode peramalan menggunakan jumlah dari kesalahan kesalahan yang absolute. Mean Absolute deviation (MAD) mengukur ketepatan ramalan dengan merata-rata kesalahan dugaan (nilai absolut masing-masing kesalahan. Nilai MAD dapat dihitung dengan menggunakan rumus sebagai berikut:
$\mathrm{MAD}=\frac{\sum_{t=1}^{n}\left|T_{t}-Y_{t}^{\prime}\right|}{n}$

Keterangan :

$\mathrm{T}_{t} \quad$ : Data permintaan periode $\mathrm{t}$

$\mathrm{Y}^{\prime}, \quad$ : Nilai ramalan pada periode $\mathrm{t}$

$\mathrm{n} \quad$ : Banyaknya periode

EOQ dihitung dengan menggunakan rumus (Erlenkotter, 1990) sebagai berikut:

$$
E O Q=\sqrt{\frac{2 \cdot D \cdot S}{H}}
$$

Keterangan :

EOQ : Jumlah optimal barang per pemasanan $\left(\mathrm{m}^{3}\right)$

D : Permintaan tahunan barang persediaan dalam unit ( $\mathrm{m}^{3} /$ tahun)

$S \quad$ : Biaya pemasangan atau pemesanan setiap pesanan $\left(\mathrm{Rp} / \mathrm{m}^{3}\right)$

$\mathrm{H} \quad$ : Biaya penahan atau penyimpanan per unit pertahun $\left(\mathrm{Rp} / \mathrm{m}^{3} /\right.$ tahun $)$

Rumus persediaan aman (Erlenkotter, 1990) adalah sebagai berikut:

$\underset{\text { Deviasi }}{\text { Standar }}=\sqrt{\frac{\sum(X-\bar{X})^{2}}{n}}$

Keterangan :

$n$ : Banyaknya periode pemesanan bahan baku.

$X$ : Jumlah penggunaan bahan baku sesungguhnya tiap periode ( $\mathrm{m}^{3} /$ tahun).

$X$ : Rata - rata penggunaan bahan baku $\left(\mathrm{m}^{3}\right)$.

Rumus titik pemesanan ulang (Erlenkotter, 1990) adalah sebagai berikut :

$\mathrm{ROP}=$ Safety stock $+($ Lead time $\times \mathrm{Q})$

Keterangan :

ROP : Titik pemesanan kembali

Lead time : Waktu tunggu (hari)

Safety Stock : Persediaan aman $\left(\mathrm{m}^{3}\right)$

$\mathrm{Q} \quad$ : Penggunaan bahan baku ratarata per hari ( $\mathrm{m}^{3} /$ hari)

Rumus TIC (Erlenkotter, 1990) adalah sebagai berikut :

$\mathrm{TIC}=\sqrt{2 D \cdot S \cdot H}$

Keterangan:

D : : Kuantitas penggunaan per periode ( $\mathrm{m}^{3} /$ tahun)

S : : Biaya per pesanan (Rp/tahun)

$\mathrm{H} \quad$ : Biaya penyimpanan per unit $\left(\mathrm{Rp} / \mathrm{m}^{3} / \mathrm{tahun}\right)$ 


\section{HASIL DAN PEMBAHASAN}

Tahapan proses produksi plywood secara garis besar terdiri dari Perencanaan produksi, Persiapan bahan, Pembuatan veneer, Pengeringan veneer, Penyiapan veneer, Perakitan, Pekerjaan akhir, Pengamanan plywood.

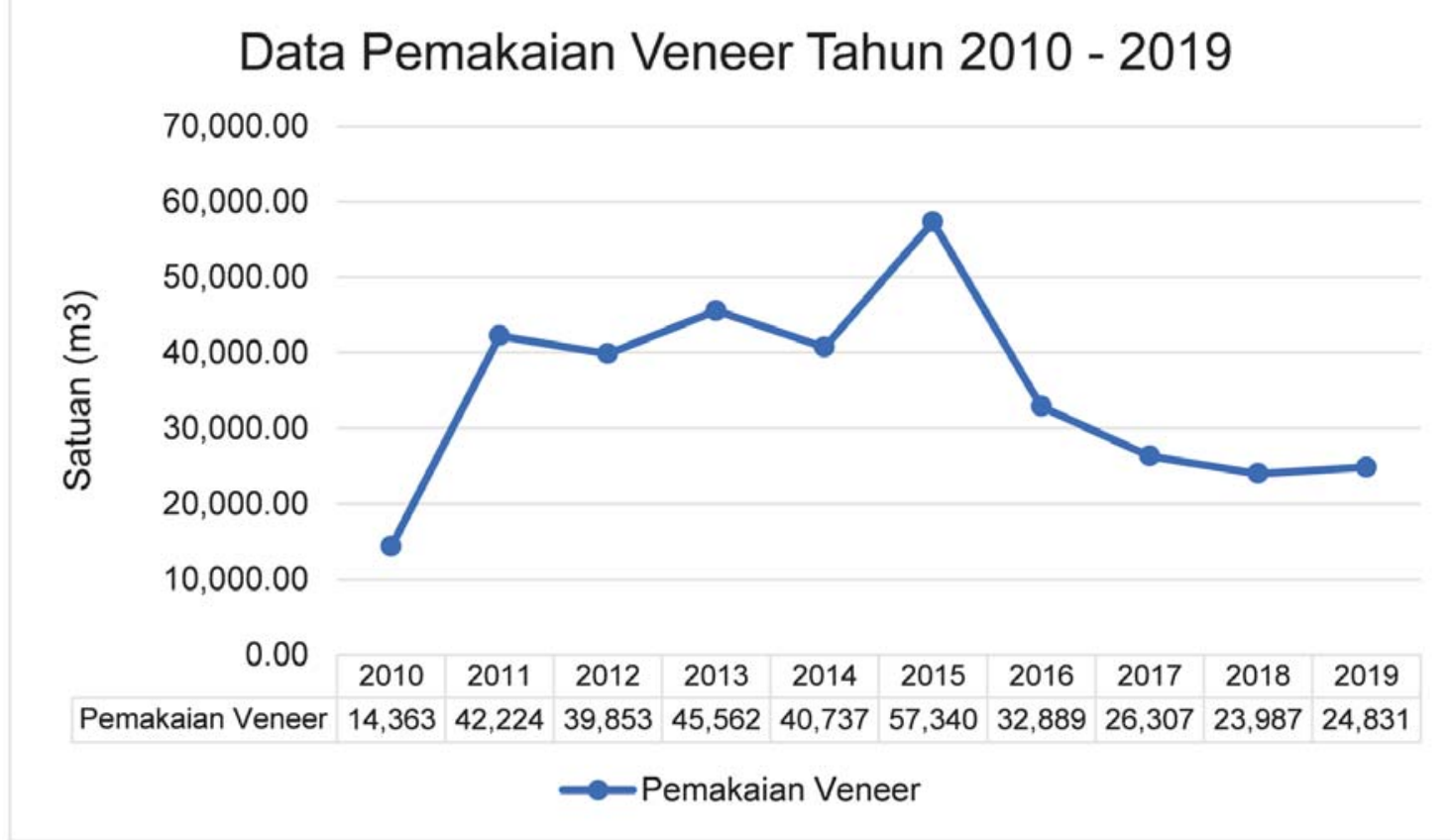

Ilustrasi 1. Grafik Pemakaian Veneer

Berdasarkan llustrasi 1 dapat diketahui bahwa jumlah pemakaian veneer cukup fluktuatif dan cenderung menurun dari tahun 2015 sampai 2019. Nilai terendah pemakaian veneer pada tahun 2010 sebanyak $14.363 \mathrm{~m}^{3}$ dikarenakan pada tahun tersebut PT Kayu Lapis Indonesia mengalami penurunan pasar dan nilai tertinggi pada tahun 2015 sebanyak $57.340 \mathrm{~m}^{3}$ dikarenakan pada tahun tersebut perusahaan menerima permintaan produksi kayu lapis untuk di ekspor yang sangat tinggi. Rata rata pemakaian veneer selama $2010-2019$ adalah $34.809 \mathrm{~m}^{3}$.

\section{Peramalan Data}

Peramalan yang dilakukan dengan mencoba 3 teknik peramalan yaitu moving average, exponential smoothing, dan least square. Percobaan dari 3 teknik tersebut didapatkan hasil :

Tabel 1. Peramalan Pemakaian Veneer Tahun 2020

\begin{tabular}{lrrr}
\hline \hline Metode & Moving Average & Exponential Smoothing & Least Square \\
\hline Jumlah $\left(\mathrm{m}^{3}\right)$ & $24.409,45$ & $24.778,89$ & $30.723,5$ \\
MAD $\left(\mathrm{m}^{3}\right)$ & $9.141,2$ & $8.988,45$ & $9.219,48$ \\
\hline
\end{tabular}

Berdasarkan Tabel 1. didapatkan hasil bahwa peramalan veneer dengan menggunakan perhitungan moving average sebesar $24.409,45 \mathrm{~m}^{3}$ dengan nilai bias $9.141,2 \mathrm{~m}^{3}$, perhitungan exponential smoothing sebesar $24.778,89 \mathrm{~m}^{3}$ dengan nilai bias $8.988,45 \mathrm{~m}^{3}$, dan perhitungan least square sebesar $30.723,5 \mathrm{~m}^{3}$ dengan nilai bias $9.219,48 \mathrm{~m}^{3}$. Nilai terendah dengan 
menggunakan teknik peramalan moving average, sedangkan nilai tertinggi dengan menggunakan teknik peramalan least square. Teknik peramalan exponential smoothing dianggap peramalan terbaik veneer pada tahun 2020 di PT Kayu Lapis Indonesia karena memiliki nilai bias atau MAD terkecil, hal ini sesuai dengan pendapat Yanti et al.
(2016) yang menyatakan bahwa metode peramalan terbaik merupakan metode peramalan yang memiliki nilai error paling rendah.

\section{Kuantitas Pemesanan Ekonomis} Perhitungan EOQ Veneer Pembelian bahan setengah jadi yang ekonomis di dasarkan pada:

Tabel 2. Data EOQ

\begin{tabular}{lc}
\hline \multicolumn{1}{c}{ Jenis Data } & Tahun 2020 \\
\hline Total kebutuhan veneer (D) & $24.778,89 \mathrm{~m}^{3}$ \\
Biaya pemesanan sekali pesan (S) & Rp 2.000.000,- \\
Biaya simpan per unit $(\mathrm{H})$ & $\mathrm{Rp} \mathrm{26.789,56,-}$ \\
\hline
\end{tabular}

Berdasarkan Tabel 2 maka pembelian veneer yang ekonomis menggunakan metode EOQ adalah sebagai berikut :

$$
\begin{aligned}
\text { EOQ } & =\sqrt{\frac{2 . D . S}{H}} \\
& =\sqrt{\frac{2 \times 24.778,89 \times 2.000 .000}{26.789,56}} \\
& =\sqrt{\frac{99.115 .560 .000}{26.789,56}} \\
& =\sqrt{3.699 .783,05} \\
& =1.923,48 \mathrm{~m}^{3}
\end{aligned}
$$

Jadi jumlah pemesanan ekonomis veneer dengan menggunakan metode EOQ di tahun 2020 sebesar 1.923,48 $\mathrm{m}^{3}$ menunjukkan bahwa pemesanan ekonomis dapat mengurangi beban perusahaan dari biaya pesan dan biaya simpan, sesuai dengan pendapat Siagian (2007) yang menyatakan bahwa tujuan dari perhitungan EOQ adalah meminimalkan biaya total terutama dari biaya pesan dan biaya simpan.

Frekuensi pemesanan veneer dengan menggunakan metode $E O Q$ dapat dihitung jumlah frekuensi pemesanan veneer dalam satu tahun. Frekuensi pembelian veneer dapat dihitung sebagai berikut:

$$
\begin{aligned}
F \quad & =\frac{D}{Q} \\
& =\frac{24.778,89}{1.923,48} \\
& =12,88 \cong 13 \text { kali }
\end{aligned}
$$

Pemesanan di tahun 2020 dilakukan 13 kali setahun. Artinya jika pembelian barang dari luar memiliki frekuensi pemesanan semakin tinggi, maka biaya pemesanan akan terpengaruh menjadi semakin besar. Sesuai dengan pendapat Sakkung dan Sinuraya (2011) yang menyatakan bahwa hubungan EOQ sebagai metode manajemen persediaan tradisional dengan biaya persediaan yang terkait didalamnya adalah jika persediaan bahan baku yang ada dalam perusahaan merupakan bahan baku yang dibeli dari luar dan bukan diproduksi atau dari dalam perusahaan, maka biaya yang terkait dengan persediaan diketahui sebagai biaya pemesanan (ordering costs) dan biaya penyimpanan (carrying costs).

\section{Persediaan Aman}

Berdasarkan perhitungan persediaan aman didapatkan hasil sebagai berikut : 
SS

$$
\begin{aligned}
& =\sqrt{\frac{\sum(X-\bar{X})^{2}}{n}} \\
& =\sqrt{\frac{1.449 .558 .517,03}{10}} \\
& =\sqrt{144.955 .851,7} \\
& =12.039,7613
\end{aligned}
$$

Jadi jumlah persediaan aman veneer sebesar 12.039,76 $\mathrm{m}^{3}$. Persediaan aman berfungsi menjaga barang dari kekurangan stock, sesuai dengan pendapat Christianti dan Wijaya (2011) yang menyatakan bahwa persediaan aman (safety stock) adalah persediaan tambahan yang diadakan untuk melindungi atau menjaga kemungkinan terjadinya kekurangan bahan. Jumlah bahan yang diperlukan untuk proses produksi sering tidak pasti sehingga diperlukan perhitungan persediaan aman, sesuai dengan Darmawan et al. (2015) yang menyatakan bahwa persediaan aman diperlukan karena dalam kenyataannya jumlah bahan baku yang diperlukan untuk proses produksi tidak selalu tepat seperti yang direncanakan.

\section{Titik Pemesanan Ulang}

Berdasarkan perhitungan titik pemesanan ulang didapatkan hasil sebagai berikut :

$$
\begin{aligned}
\text { ROP } & =\text { Safety stock }+(\text { Lead time } \times Q) \\
& =12.039,76+\left(3 \text { hari } \times 77,43 \mathrm{~m}^{3} \text { /hari }\right) \\
& =12.039,76+232,3 \\
& =12.272,06 \\
& \text { Jadi titik pemesanan ulang }
\end{aligned}
$$

sebesar $12.272,06 \mathrm{~m}^{3}$. Titik pemesanan ulang berfungsi menentukan titik untuk melakukan order kembali, sesuai dengan pendapat Simbar et al. (2014) yang menyatakan bahwa Reoder point adalah saat atau waktu tertentu perusahaan harus mengadakan pemesanan bahan dasar kembali. Perhitungan titik pemesanan ulang harus dihitung dengan cermat karena jika keliru dapat mengakibatkan kekurangan bahan atau penambahan biaya penyimpanan, sesuai dengan pendapat Chaharsooghi et al. (2011) yang menyatakan bahwa Reorder Point harus dihitung secara cermat dan tepat, karena bila terlambat akan berakibat munculnya biaya kekurangan bahan sedangkan jika terlalu cepat akan berakibat timbulnya biaya penyimpanan tambahan.

\section{Total Biaya Persediaan}

Berdasarkan metode EOQ maka total biaya persediaan veneer di PT. Kayu Lapis Indonesia adalah sebagai berikut:

$$
\begin{aligned}
& \mathrm{TIC}=\sqrt{2 D . S . H} \\
& =\sqrt{2 \times 24.778,89 \times 2.000 .000 \times 26.789,56} \\
& =\sqrt{2.655 .262 .241 .553 .600} \\
& =\operatorname{Rp} 51.529 .236,76,-
\end{aligned}
$$

Jadi total biaya persediaan yang harus ditanggung perusahaan di tahun 2020 bila menggunakan metode EOQ sebesar Rp 51.529.236,76,-. Biaya total persediaan dengan menggunakan metode EOQ merupakan salah satu fungsi persediaan menghemat biaya perusahaan, sesuai dengan pendapat Tuerah (2015) yang menyatakan bahwa fungsi persediaan Economic Lot Sizing melalui penyimpanan persediaan, perusahaan dapat memproduksi dan membeli sumber-sumber daya dalam kuantitas yang dapat mengurangi biaya-biaya per unit dengan persediaan lot size ini akan mempertimbangkan penghematan-penghematan.

\section{KESIMPULAN}

Hasil kesimpulan penelitian ini adalah proses produksi plywood di PT Kayu Lapis Indonesia meliputi perencanaan produksi, persiapan bahan, pembuatan veneer, pengeringan veneer, penyiapan veneer, perakitan, pemotongan plywood, dan pengamanan plywood. Peramalan kebutuhan veneer 
beli dengan menggunakan metode exponential smoothing didapatkan hasil pada tahun 2020 PT. Kayu Lapis Indonesia membutuhkan veneer sebesar 24.778,89 $\mathrm{m}^{3}$ dengan kesalahan peramalan (MAD) alpha 0,9 sebesar $8.988,45 \mathrm{~m}^{3}$. Kemudian kebutuhan tersebut dihitung kuantitas pemesanan ekonomis (EOQ) yang mendapatkan hasil sebesar 1.923,48 $\mathrm{m}^{3}$ dengan frekuensi pemesanan dilakukan 13 kali setahun. Persediaan aman veneer 12.039,76 $\mathrm{m}^{3}$ dan titik pemesanan ulang sebesar $12.272,06 \mathrm{~m}^{3}$. Biaya total persediaan veneer yang harus ditanggung perusahaan bila menggunakan metode kuantitas pemesanan ekonomis sebesar Rp 51.529.236,76,--.

\section{SARAN}

Saran untuk PT. Kayu Lapis Indonesia adalah untuk memperhatikan dan mempertimbangkan biaya persediaan karena hal tersebut dapat meningkatkan efisiensi dan mengurangi beban biaya perusahaan.

\section{DAFTAR PUSTAKA}

Chaharsooghi, S. K., Heydari, J., \& Kamalabadi, I. N. 2011. Simultaneous coordination of order quantity and reorder point in a two-stage supply chain. J. Computers \& Operations Research. 38 (12): 1667-1677.

Christianti, M., \& Wijaya, L. 2011. Aplikasi pembelian,"penjualan obat dan laporan keuangan dengan menerapkan manajemen persediaan". J. Sistem Informasi. $6(2): 127-141$.
Darmawan, G. A., Cipta, W., Yulianthini, N. N., \& SE, M. 2015. Penerapan economic order quantity (EOQ) dalam pengelolaan persediaan bahan baku tepung pada usaha pia ariawan di Desa Banyuning tahun 2013. J. Jurusan Manajemen. 3(1):1-10.

Erlenkotter, D. 1990. Ford Whitman Harris and the economic order quantity model. J. Operations Research. $38(6)$ : 937-946.

Komalasari, W. B. 2008. Prediksi penawaran dan permintaan kedelaidengan a $\mathrm{n}$ a I is is deret waktu. J. Informatika Pertanian. 17 (2): 1195-1209.

Sakkung, C. V., \& Sinuraya, C. 2011. Perbandingan metode EOQ (Economic Order Quantity) dan JIT (Just In Time) terhadap efisiensi biaya persediaan dan kinerja non-keuangan (Studi Kasus Pada PT. Indoto Tirta Mulia). J. IImiah Akuntansi. 2 (5) : 20-31.

Siagian, Y. M. 2007. Aplikasi Supply Chain Management. Grasindo, Jakarta.

Simbar, M., Katiandagho, T. M., Lolowang, T. F., \& Baroleh, J. 2014. Analisis pengendalian persediaan bahan baku kayu cempaka pada industri mebel dengan menggunakan metode EOQ (Studi Kasus Pada Ud. Batu Zaman). J. IImiah Cocos. $5(3): 31-46$.

Tuerah, M. C. 2015. Analisis pengendalian persediaan bahan baku ikan tuna pada CV. Golden KK. J. Riset Ekonomi, Manajemen, Bisnis dan Akuntansi. 2 (4) : 524-536. 
Ulya, N. A., \& Yunardy, S. 2006. Analisis peranan sektor kehutanan dalam perekonomian Indonesia: sebuah pendekatan model inputoutput. J. Penelitian Sosial dan Ekonomi Kehutanan, 3(1): 1-13.

Wildana, F. N., \& Utami, E. U. S. 2017. Analisis sistem pengendalian persediaan atas barang dagang pada CV. Sumber Alam Sejahtera Tegal. Monex: J. Research Accounting Politeknik Tegal, 6 (2) : 252-255.
Yanti, N. P. L. P., Tuningrat, I. M., \& Wiranatha, A. A. S. 2016. Analisis peramalan penjualan produk kecap pada perusahaan kecap manalagi Denpasar Bali. J. Rekayasa dan Manajemen Agroindustri, 4 (1) : 72-81. 